\title{
Comparative Efficacy Trials with Two Different Bacillus thuringiensis Serovar kurstaki Strains against Gypsy Moth in Mediterranean Cork Oak Forests
}

\author{
Maurizio Olivieri ${ }^{1}\left(\mathbb{D}\right.$, Roberto Mannu ${ }^{1, *}$, , Luca Ruiu ${ }^{1}\left(\mathbb{D}\right.$, Pino A. Ruiu ${ }^{2}$ and Andrea Lentini ${ }^{1}(\mathbb{D}$ \\ 1 Dipartimento di Agraria, Università degli Studi di Sassari, 07100 Sassari, Italy; molivieri@uniss.it (M.O.); \\ lucaruiu@uniss.it (L.R.); lentini@uniss.it (A.L.) \\ 2 Servizio Ricerca per la Sughericoltura e la Selvicoltura, AGRIS Sardegna, 07029 Tempio Pausania, Italy; \\ paruiu@agrisricerca.it \\ * Correspondence: rmannu@uniss.it
}

check for

updates

Citation: Olivieri, M.; Mannu, R.;

Ruiu, L.; Ruiu, P.A.; Lentini, A.

Comparative Efficacy Trials with Two

Different Bacillus thuringiensis Serovar kurstaki Strains against Gypsy Moth in Mediterranean Cork Oak Forests. Forests 2021, 12, 602. https://doi.org/ $10.3390 /$ f12050602

Academic Editors: Young-Seuk Park and Won Il Choi

Received: 16 April 2021

Accepted: 7 May 2021

Published: 11 May 2021

Publisher's Note: MDPI stays neutral with regard to jurisdictional claims in published maps and institutional affiliations.

Copyright: (C) 2021 by the authors Licensee MDPI, Basel, Switzerland. This article is an open access article distributed under the terms and conditions of the Creative Commons Attribution (CC BY) license (https:/ / creativecommons.org/licenses/by/ $4.0 /)$.
Abstract: The efficacy of two formulations (Foray ${ }^{\circledR} 76 \mathrm{~B}$ AVIO and Rapax ${ }^{\circledR}$ AS AIR) containing different Bacillus thuringiensis kurstaki (Btk) strains (ABTS-351 and EG-2348, respectively) was evaluated against Lymantria dispar larval populations in cork oak forests in Sardinia (Italy), in 2018 and 2019. The experimental design involved the following treatments: (I) untreated control; (II) Foray ${ }^{\circledR} 76 \mathrm{~B}$ at the dose of $2.0 \mathrm{~L} / \mathrm{ha}$; (III) Foray ${ }^{\circledR} 76 \mathrm{~B}$ at the dose of $2.5 \mathrm{~L} / \mathrm{ha}$; (IV) Rapax ${ }^{\circledR}$ AS AIR at the dose of $2.0 \mathrm{~L} / \mathrm{ha}$. Aerial applications were carried out using a helicopter equipped with four electronic rotary atomizers adjusted to sprinkle 160 micron-sized drops. Btk efficacy was evaluated by assessing the larval density reduction 7,14 , and 21 days after the application in each experimental plot in comparison with an untreated check. In addition to field surveys, the mortality of second and third instar larval samples, randomly collected from each plot after treatment and fed with foliage from the same plot, was determined in the laboratory. All Btk treatments were similarly effective, and no differences in larval density reduction among Btk strains and doses were found in either year. Twenty-one days after application, the average larval density reduction in the field was approximately $70 \%$ in all treated plots in 2018, whereas in 2019 it reached $80 \%$ only in areas treated with Foray 76B at $2.5 \mathrm{~L} /$ ha. Laboratory observations showed that all $B t k$-based products were effective against gypsy moth larvae, with significant differences in mortality between untreated control and the different $B t k$ treatments. Our results shed light on the possibility of alternating different $B t k$ strains for resistance management purposes and of applying lower doses than labeled, in order to achieve cost savings for product shipment and distribution and to reduce the environmental impact.

Keywords: Lymantria dispar; biopesticides; aerial application; entomopathogens; Bacillus thuringiensis

\section{Introduction}

Cork oak (Quercus suber L.) is an evergreen species typical of Mediterranean pure and mixed forests or included in extensive agroforestry systems [1]. In addition to being biodiversity hotspots $[2,3]$, cork oak forests are important economic resources in regard to cork production and their usefulness as pastureland.

A major threat to Mediterranean cork oak is the gypsy moth, Lymantria dispar (L.) (Lepidoptera: Erebidae), one of the main forest pest defoliators worldwide [4-6]. Gypsy moth is a univoltine species whose larvae can feed and develop on more than 300 different plant species [7-9], even though Quercus species are the main hosts in natural environments $[10,11]$. Spring larval feeding behavior, mostly targeting young oak shoots, causes a significant loss of the photosynthesizing surface, which leads to a tree growth decrease and consequent cork production reduction of up to $60 \%$ in totally defoliated trees and $40 \%$ in partially defoliated trees [12]. Moreover, the ordinary development of infested trees might be affected in the following year too, resulting in delayed bud burst and additional cork growth reduction [13]. 
In order to reduce gypsy moth infestations and consequent damage to trees, different control strategies have been developed [14-18]. Of these, the application of Bacillus thuringiensis serovar kurstaki $(B t k)$ is considered one of the most effective methods to reduce larval population density $[16,17]$ with few biological and practical limitations $[19,20]$. Btk application success against $L$. dispar strictly depends on several technical aspects, including timing, which should target second instar larvae [19,21], appropriate dose [14,22], and droplet size [23]. In Sardinia (Italy), according to a multi-year experiment in which various strains and formulations were applied by employing diverse aerial distribution methods against different gypsy moth generations [24,25], Btk was able to protect cork oak forests from this pest [25]. Based on these studies, Foray ${ }^{\circledR} 48 \mathrm{~B}$ and Foray ${ }^{\circledR} 76 \mathrm{~B}$ (Valent Bioscience Corporation, Libertyville, Illinois, USA) suspension concentrates (SC) of strain ABTS-351 authorized against gypsy moth were the Btk-based formulations providing the highest efficacy [26]. Among these two products with equal effectiveness, Foray ${ }^{\circledR} 76 \mathrm{~B}$ is recommended to be used at a nearly half dose, which allows cost saving for product shipment and distribution [19].

Btk-based formulations normally used to control Lepidopteran defoliators are suspension concentrates (SC) of spores and crystals, containing insecticidal Cry proteins, acting by ingestion. Activated $\mathrm{Cry}$ proteins bind to specific receptors covering the plasma membrane of the insect's midgut epithelium, determining the formation of amphiphilic pores and a subsequent abnormal flux of ions and water into the epithelial cells [27]. Consequently, affected gut cells lyse [28] and infected larvae undergo paralysis and death, eventually exhibiting bacterial septicemia [29]. Although Btk acts specifically against Lepidoptera, susceptibility to toxins can vary depending on Btk strains [30,31]. For example, the tent caterpillar, Malacosoma neustria (L.) (Lepidoptera Lasiocampidae), which is often considered a secondary pest of cork oak forests [5,11], was more susceptible to ABTS-351 strain than L. dispar in application experiments conducted in cork oak forests in Sardinia [18]. Such differences were shown to be related to different degrees of Cry toxin affinity for midgut receptors, resulting in different amounts of amphiphilic pore formation on epithelial cells in susceptible insect species [32]. On the other hand, full insecticidal action of a Btk-based formulation is achieved when a sufficient number of spores and Cry proteins are ingested by young larvae [22], which is strictly related to the intrinsic features of the formulation and the way it is applied [33]. Therefore, the characteristics of the formulation and the insecticidal traits of the $B t k$ strain it contains represent key factors to maximize gypsy moth containment efficacy in the field, enabling a longer residual effect.

Since the dose, formulation, and strain of Btk products are recognized as the main features determining a successful application against $L$. dispar, large-scale comparative trials with different Btk-based products and doses were performed in 2018 and 2019 in two cork oak forests in Sardinia. Experiments, including field and laboratory work, involved the two Btk strains ABTS-351 and EG-2348, containing a different assortment of Cry toxins.

\section{Materials and Methods}

\subsection{Experimental Products}

Two aqueous suspension concentrate (SC) Btk formulations were used in this study: (1) Foray ${ }^{\circledR} 76 B$ AVIO (Sumitomo Chemical Agro Europe S.A.S., Machelen, Belgium), containing 20 billion international units (BIU)/L of Btk strain ABTS-351 expressing the insecticidal crystal toxins Cry1A(a), Cry1A(b), Cry1A(c), and Cry2A and (2) Rapax ${ }^{\circledR}$ AS AIR (Biogard, CBC Europe S.r.l., Grassobbio, Italy), containing 24 BIU/L of Btk strain EG-2348 and $\operatorname{Cry} 1 \mathrm{~A}(\mathrm{a}), \operatorname{Cry} 1 \mathrm{~A}(\mathrm{c})$, and Cry2A proteins. Foray and Rapax were authorized for aerial applications in Sardinian forests by Reg. n. 17,191 and 17,190 in 2018 and by Reg. n. 17,393 and 17,394 in 2019, issued by the Italian Ministry of Health according to art. 53, p. 1, Regulation (CE) n. 1107/2009. 


\subsection{Study Area and Experimental Design}

Trials were carried out in 2018 and 2019 in pure cork oak forests in northern and eastern Sardinia, respectively, according to a randomized complete block design with three replicates (plots) of approximately 200 ha each, including the following treatments: (1) Foray ${ }^{\circledR} 76 \mathrm{~B}$ AVIO applied at the dose of $2.0 \mathrm{~L} /$ ha (hereafter called Foray 2.0); (2) Foray ${ }^{\circledR}$ $76 \mathrm{~B}$ AVIO applied at the recommended dose of $2.5 \mathrm{~L} /$ ha (hereafter called Foray 2.5); (3) Rapax ${ }^{\circledR}$ AS AIR applied at the dose of $2.0 \mathrm{~L} /$ ha (hereafter called Rapax); (4) untreated check (control). Btk-based formulations were sprayed at an ultralow volume using a helicopter equipped with a 12-m long bar with four rotary atomizers (model AU) regulated to sprinkle 160 micron-sized drops. Spraying equipment included a flow control system allowing for the management of insecticide distribution rates at variable helicopter speeds. Btk applications were made on 12 May and 11 May in 2018 and 2019, respectively, under optimal weather conditions, corresponding to an average temperature ranging from 19 to $28^{\circ} \mathrm{C}, 30-60 \%$ relative humidity, and wind speeds below $1-2 \mathrm{~m} / \mathrm{s}$. Treatments targeted a gypsy moth larval population mainly in the second instar, being highly susceptible to the Btk action [34].

In both years, the level of gypsy moth infestation in the study areas, estimated by assessing the number of egg masses along a standardized 40-plant transect (economic damage threshold $=100$ eggs), clearly indicated this species fell in a retrogradation phase within its multi-year cycle, as determined by analysis of data from network stations established in Sardinia since 1980 [35] and including more than 680 permanent monitoring sites [36]. Based on the close correlation between egg mass density and defoliation level in the following spring, in Sardinia, total defoliation is expected when the 100-egg threshold is reached [19]. Despite being in a retrogradation phase, the average density of $L$. dispar recorded in both 2018 and 2019 was higher than the action threshold, thus justifying the need for a phytosanitary application.

\subsection{Evaluation of Btk Treatments}

The effect of Btk applications against gypsy moth larvae was evaluated under field and laboratory conditions. In the field, gypsy moth larval population density was estimated in each plot before spraying and 7, 14, and 21 days after spraying. Larval density was assessed by counting the number of larvae on four randomly chosen shoots (approximately $30 \mathrm{~cm}$ in length) per tree from 10 consecutive cork oak trees selected along a linear transect (40 shoots/site/sampling date). In addition, larvae were identified according to different instars. Larval density reduction in treatment $x$ after $t$ days $\left(\Delta D_{x t}\right)$ was calculated as

$$
\Delta D_{x t}=\frac{D_{x 0}-D_{x t}}{D_{x 0}} \times 100
$$

where $D_{x 0}$ is the initial larval density in treatment $x$ at sampling time 0 (i.e., before spraying), and $D_{x t}$ is the larval density $t$ days after the $B t k$ applications in treatment $x$.

In the laboratory, the larval mortality was evaluated on second and third instars randomly collected from each plot a few hours after each spraying. Groups of one hundred larvae from each plot were transferred into aerated plastic containers $18 \mathrm{~cm}$ in diameter and $25 \mathrm{~cm}$ in height (Kartell ${ }^{\mathrm{TM}}$ Inc., New York, NY, USA) with a perforated cup. To prevent larvae escaping from the upper holes, a portion of non-woven fabric was inserted between the cap and the top edge of the container. Throughout the entire breeding period, the larvae were fed ad libitum with fresh cork leaves from their original treated plot. Gypsy moth larvae were reared until pupation and the number of live and/or dead larvae, as well as the total number of pupae, was recorded every $2-3$ days.

\subsection{Statistical Analysis}

All statistical analyses were performed using R statistical software version 3.10 [37]. Differences among treatments in instars composition were evaluated before Btk application for all years using a $\chi^{2}$ test for independence $(p<0.05)$. Moreover, one-way Analysis 
of Variance (ANOVA) followed by Tukey post hoc test at 0.05 level of significance were performed to test for differences in larval infestation (i.e., average number of larvae counted on 40 shoots) before treatment.

The efficacy of different $B t k$ treatments was evaluated by considering larval density reduction compared to initial density. In order to take into account the natural population decrease, larval reduction due to $B t k$ treatments were corrected for natural mortality $\left(C_{x t}\right)$ using the Schneider-Orelli formula [38]:

$$
C_{x t}=\frac{\Delta D_{x t}-\bar{D}_{C t}}{100-\bar{D}_{C t}} \times 100
$$

where $\Delta D_{x t}$ is the larval density reduction in treatment $x$ after $t$ days, and $\bar{D}_{C t}$ is the average larval density reduction $t$ days after the $B t k$ applications in untreated control. Differences in corrected larval reduction among $B t k$ treatments were tested separately within sampling times (i.e., 7, 14, and 21 days after application) using ANOVA followed by Tukey's test at significance level of 0.05 .

Data obtained from laboratory assessments were used to evaluate both larval survival and density reduction under controlled conditions. Survival analysis was performed separately for each year of observation using a mixed effects Cox proportional hazard model using survival (version 3.2-11) [39], and coxme (version 2.2-16) [40] packages in R. In each model, treatments were considered as fixed factors and cage (i.e., replicate) as a random effect factor. Further post-hoc analysis was performed using multcomp (version 1.4-16) package in R [41], applying a Bonferroni correction for multiple testing. Larval density reduction corrected using Schneider-Orelli was calculated at 7, 14, and 21 days after treatment in order to evaluate the individual effect of Btk against gypsy moth larvae under laboratory conditions. One-way ANOVA followed by Tukey's test at 0.05 level of significance was used to test for differences among treatments.

\section{Results}

In both experimental years, Btk formulations were applied when the gypsy moth larval population was mainly in the second instar (Table 1). Statistical differences in instar distribution among treatments were found in $2018\left(\chi^{2}=108.3, \mathrm{df}=6, p<0.05\right)$, and 2019 $\left(\chi^{2}=282.4, \mathrm{df}=6, p<0.05\right)$. In 2018, plots treated with Foray 2.5 were characterized by a higher proportion of third instars than other plots, whereas plots sprayed with Rapax showed a significantly higher proportion of first instars (Table 1). In 2019, although treatments targeted a larval population mainly in the second instar, the presence of fourth instars was observed in all treated areas except those treated with Rapax (Table 1). No statistical differences in larval density among treatments were found before microbiological applications in either 2018 or 2019 (Table 2), indicating a similar level of infestation in all experimental areas.

Table 1. Occurrences of Lymantria dispar larval instars observed in 2018 and 2019 in untreated (control) areas and areas treated with Foray ${ }^{\circledR}$ 76B AVIO and Rapax ${ }^{\circledR}$ AS AIR 2018 in Sardinia (Italy). Pearson standardized residuals measuring the deviation from expected values are reported in brackets (+ = positive deviation; $-=$ negative deviation).

\begin{tabular}{llcccc}
\hline Year & Treatments & First Instar & Second Instar & Third Instar & Fourth Instar \\
\hline \multirow{2}{*}{2018} & Foray 2.0 L/ha & 242 & 521 & 121 & - \\
& Foray 2.5 L/ha & 278 & $527(-)$ & $218(+)$ & - \\
& Rapax & $106(+)$ & 120 & $8(-)$ & - \\
& Control & 192 & $467(+)$ & $65(-)$ & - \\
\hline \multirow{2}{*}{2019} & Foray 2.0 L/ha & $11(-)$ & $190(-)$ & $163(+)$ & $24(+)$ \\
& Foray 2.5 L/ha & 15 & 118 & $61(+)$ & 2 \\
& Rapax & 42 & 308 & $46(-)$ & 0 \\
& Control & 48 & $394(+)$ & $26(-)$ & $1(-)$ \\
\hline
\end{tabular}


Table 2. Average (mean \pm standard error) Lymantria dispar larval density occurred in 2018 and 2019 in untreated and Btk treated plots before insecticide applications. Analysis of Variance (ANOVA) statistics and $p$-value are reported.

\begin{tabular}{ccccccc}
\hline Year & Foray 2.0 L/ha & Foray 2.5 L/ha & Rapax & Control & F & $p$ \\
\hline 2018 & $294.7 \pm 101.3$ & $247.0 \pm 19.2$ & $78.0 \pm 35.7$ & $241.3 \pm 65.9$ & 2.20 & 0.17 \\
2019 & $129.7 \pm 61.6$ & $65.3 \pm 13.7$ & $132 \pm 12.2$ & $156.3 \pm 51.9$ & 0.89 & 0.49 \\
\hline
\end{tabular}

The analysis of larval density reduction in the field exclusively due to Btk treatments applied in 2018 showed a comparable percentage of reduction among treatments $7\left(F_{2,6}=0.27\right.$, $p=0.77), 14\left(\mathrm{~F}_{2,6}=1.13, p=0.39\right)$, and $21\left(\mathrm{~F}_{2,6}=0.12, p=0.89\right)$ days after spraying (Figure 1a). Similarly, no differences in corrected larval reduction were found in 2019 throughout the sampling period ( 7 days after application: $\mathrm{F}_{2,6}=3.31, p=0.12 ; 14$ days after application: $\mathrm{F}_{2,6}=0.08, p=0.93 ; 21$ days after application: $\mathrm{F}_{2,6}=0.88, p=0.50$ ) (Figure $1 \mathrm{~b}$ ).

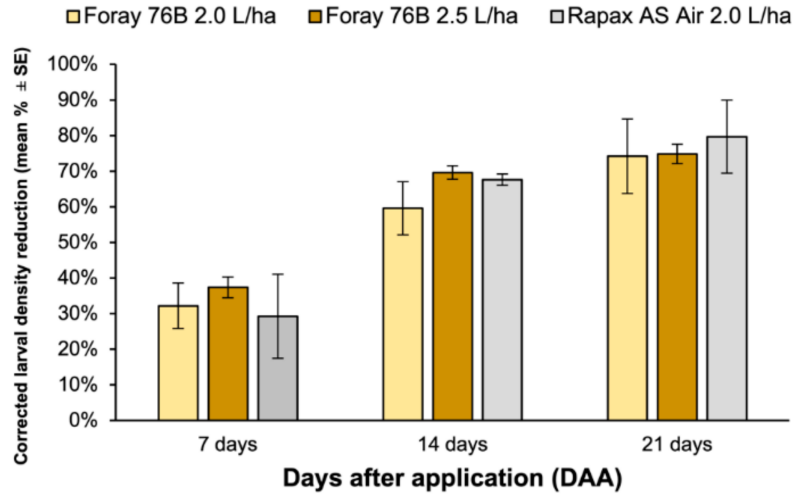

(a)

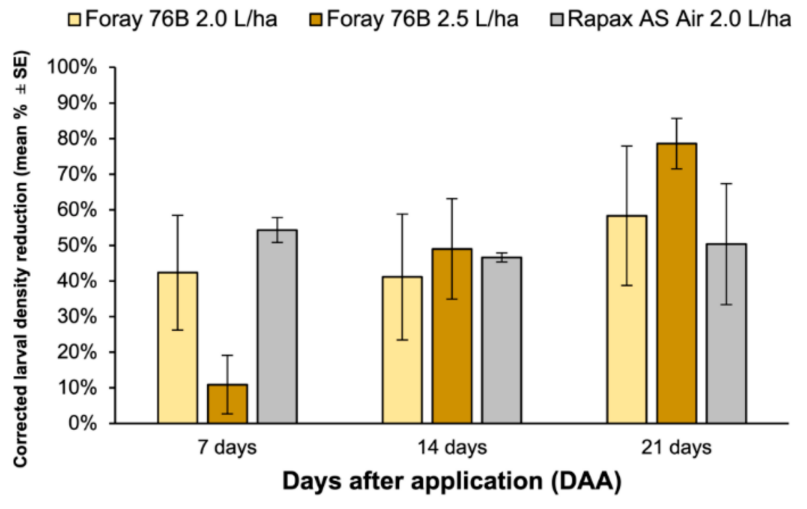

(b)

Figure 1. Percentage reduction of Lymantria dispar larval population caused by application of Foray $76 \mathrm{~B}^{\circledR}(2.0 \mathrm{~L} / \mathrm{ha}$ and $2.5 \mathrm{~L} / \mathrm{ha}$ ) and Rapax $\mathrm{AVIO}^{\circledR}$ 7, 14, and 21 days in (a) 2018 and (b) 2019 panel. Larval reductions were corrected with the Schneider-Orelli formula.

Survival of field-collected larvae maintained in the laboratory in 2018 was different among treatments $\left(\chi^{2}=210.03, p<0.01\right)$, with a significantly higher survival rate in untreated control than other treatments. Survival observed in larvae fed with foliage sampled from areas treated with Rapax was comparable to larvae from Foray 2.0-treated areas $(\mathrm{z}=-2.48, p=0.08)$, whereas it was significantly lower in respect to larvae fed with Foray 2.5-treated foliage $(\mathrm{z}=-3.96, p<0.01)$.

No difference in survival was found between larvae fed with Foray 2.0- and Foray 2.5-treated foliage $(\mathrm{z}=1.49, p=0.81)$. The survival of larvae fed with untreated foliage was approximately $80 \%$ at the end of the laboratory observations (30 days), in contrast to $24.7 \%$, $10.0 \%$, and $6.3 \%$ in larvae fed with foliage treated with Rapax, Foray 2.0, and Foray 2.5, respectively (Figure 2a). A similar pattern was observed in laboratory observations conducted in 2019 (Figure 2b), in which the survival of larvae fed with Btk-treated foliage after 30 days was slightly lower than that observed in larvae from untreated areas (Foray $2.0=1.3 \%$; Foray $2.5=4.3 \%$; Rapax $2.0=10.0 \%$; untreated control $=68.3 \%$ ). In these experiments, significant differences in survival among treatments were found $\left(\chi^{2}=339.92, p<0.01\right)$, with a higher survival rate of larvae fed on untreated foliage than those fed with Foray $2.0(z=-17.25$, $p<0.01)$, Foray $2.5(z=-15.66, p<0.01)$, and Rapax $(z=-15.76, p<0.01)$. 


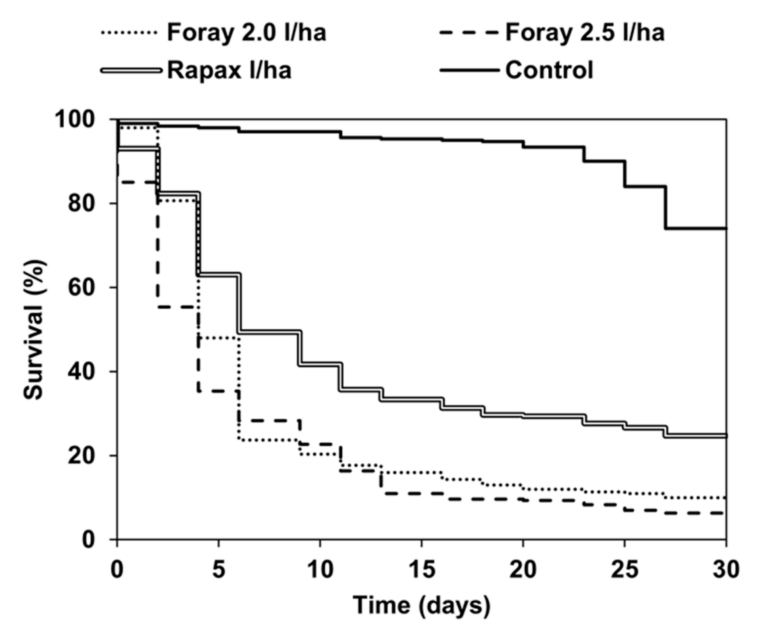

(a)

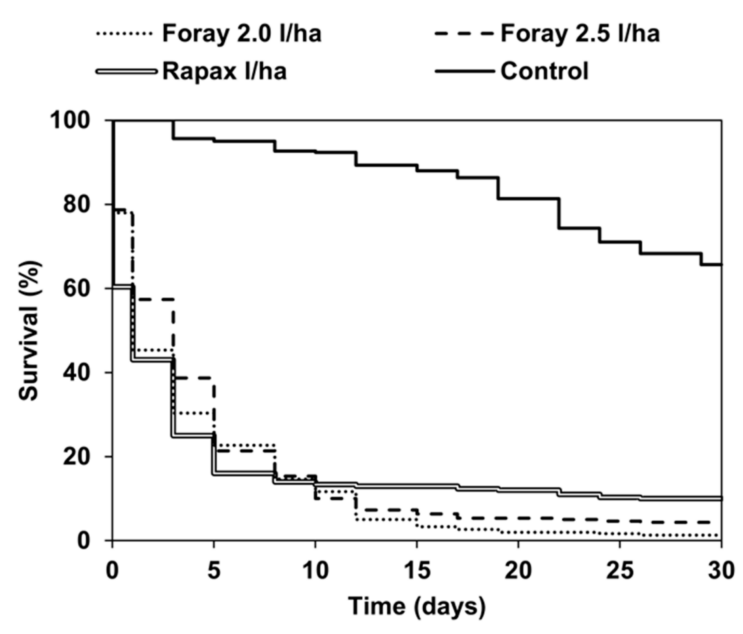

(b)

Figure 2. Survival of Lymantria dispar larvae fed in the laboratory with untreated and Btk-treated foliage in (a) 2018 and (b) 2019.

The corrected larval mortality observed in the laboratory in 2018 and 2019 is illustrated in Figure 3a,b, respectively. In 2018, larval mortality attributable exclusively to Btk formulations was similar $7\left(\mathrm{~F}_{2,6}=3.79, p=0.09\right)$ and $14\left(\mathrm{~F}_{2,6}=5.24, p=0.05\right)$ days after their application in all treatments (Figure 3a). However, significant differences among $B t k$-based formulations were found 21 days after sprayings, with a lower mortality in larvae fed with Rapax than those fed with Foray at both assayed doses $\left(F_{2,6}=9.69, p=0.01\right)$. In 2019 , the average corrected larval mortality observed in the laboratory seven days after application was, respectively, $75.4 \%, 73.9 \%$, and $59.2 \%$ for larvae fed with Foray 2.0, Rapax, and Foray 2.5. Larval density decreased over time and the reduction of reared larvae reached more than $80 \%$ in all treatments 21 days after the application. No differences in larval mortality among treatments attributable to $B t k$ were found at different times of observation ( 7 days after application: $\mathrm{F}_{2,6}=0.51, p=0.62 ; 14$ days after application: $\mathrm{F}_{2,6}=1.03, p=0.41 ; 21$ days after application: $\mathrm{F}_{2,6}=2.39, p=0.17$ ) (Figure $3 \mathrm{~b}$ ).

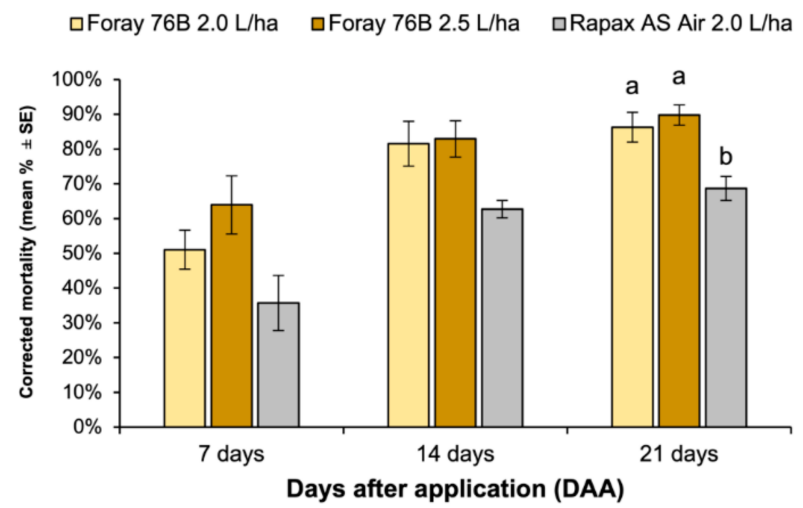

(a)

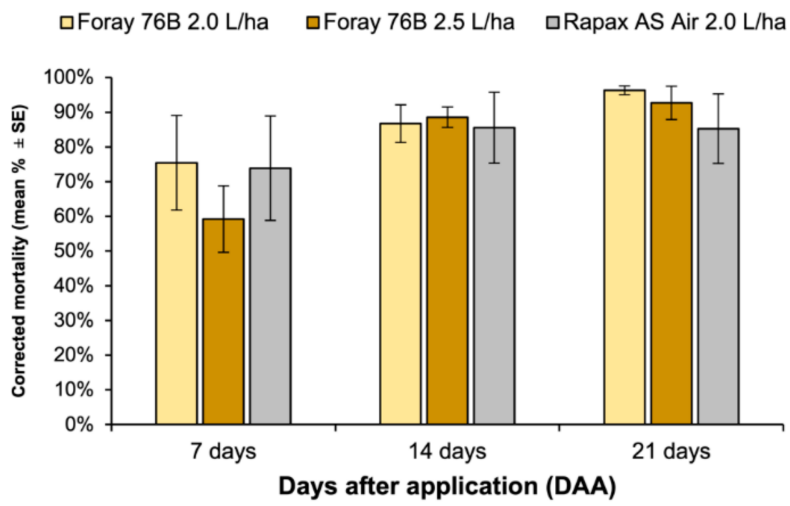

(b)

Figure 3. Lymantria dispar mortality (\%) under laboratory conditions caused by Foray $76 \mathrm{~B}^{\circledR}(2.0 \mathrm{~L} / \mathrm{ha}$ and $2.5 \mathrm{~L} / \mathrm{ha})$ and Rapax $\mathrm{AVIO}^{\circledR} 7,14$, and 21 days in (a) 2018 and (b) 2019 panel. Mortality was corrected with the Schneider-Orelli formula.

\section{Discussion}

All Btk applications in this study successfully contributed to the reduction in L. dispar larval populations in the forest. Foray ${ }^{\circledR} 76 \mathrm{~B}$ AVIO, commonly used in large-scale gypsy moth management programs in Sardinia [19], caused a significant decrease in larval density 
when applied either at a standard $(2.5 \mathrm{~L} / \mathrm{ha})$ or lower $(2.0 \mathrm{~L} / \mathrm{ha})$ dose. The efficacy of $\operatorname{Rapax}^{\circledR}$ AS Air, which is characterized by a different $B t k$ strain (i.e., EG-2348), was generally comparable to Foray ${ }^{\circledR}$ 76B AVIO (i.e., ABTS-351). However, the latter, as a whole, appeared more effective in controlling the L. dispar larval population. On the other hand, the efficacy of these Btk products observed in 2018 and 2019, compared to the untreated control areas, was less evident than expected due to the target population being under retrogradation. Another aspect affecting efficacy comparisons between the two experimental years is the larval age at the time of application, which is a factor correlated to Btk effectiveness [22]. In 2019 , the larval population at the time of application was characterized by a higher larval age than that in 2018. Therefore, to achieve the same level of mortality when targeting older larvae, a higher dose would have been needed [14,22]. Nevertheless, differences in larval age are also related to other natural control factors affecting population. Older larvae which survive $B t k$ treatments are exposed for a longer time to several biotic and abiotic mortality factors, which act more consistently during a gypsy moth retrogradation phase [42]. Among these, the biological control agent community, whose population is host-density dependent, expresses its highest potential during retrogradation [42-45]. The effects of the complexity of natural phenomena affecting Btk efficacy evaluations based on population density measurements before and after treatments and during retrogradation were mitigated in this study by including laboratory observations of larval samples collected from treated plots. This approach allowed the demonstration of clear treatment efficacy, with larvae feeding on non-treated foliage showing a significantly higher survival rate than that of larvae from treated areas in both years (Figure 2a,b).

Based on this study, both $B t k$ formulations were equally effective in attaining larval density reduction in the field. The EG-2348 strain characterizing Rapa ${ }^{\circledR}$ AS Air formulation was previously assayed against $L$. dispar and $M$. neustria populations, proving to be effective when applied on individual cork oak trees [17]. However, in those experiments, Btk suspension was diluted with water and applied from the ground with an atomizer at a volume of $10 \mathrm{~L} / 100 \mathrm{~m}^{2}$. No recommendations for aerial application of this product were available, but our results demonstrated that the same procedures in use in Sardinia since the 1990s for aerial application of Foray ${ }^{\circledR}[19,24,25]$ can also be used effectively for Rapax ${ }^{\circledR}$. This aspect is not secondary to achieving an appropriate size and density of suspension droplets, which is strictly dependent on the type of distribution and the physico-chemical features of the formulation [33]. These results provide important practical information for the aerial application of Foray ${ }^{\circledR} 76 \mathrm{~B}$ AVIO and Rapax ${ }^{\circledR}$ AS AIR, as both are aqueous suspensions. Our results align with previous trials reporting the effectiveness of $B t k$-based SC formulations on different Lepidopteran species affecting forest and agricultural crops, under different field conditions [17,46].

Another relevant finding emerging from this work is the availability of two formulations containing Btk strains bearing different $\mathrm{Cr} y$ genes, both resulting in a satisfactory pest control capability. This relates to the need to develop a longer-term control strategy involving the alternate or combined use of different strains, according to a resistance management approaches based on modes of action diversification. Insect resistance to $B t$ toxins was in fact reported in both laboratory and field conditions [47-49], being developed by different mechanisms, most of which are still under investigation [32]. Possible adaptation to $B t$ toxins by natural populations should therefore also be considered in the forest environment, where the selection pressure caused by the application of the same active substance for several years may facilitate the onset of resistance [50]. In addition to strains rotation, resistance management should include the maintenance of treatment-free areas as a reserve of $B t$-sensitive populations.

The present study indicated similar efficacy of using the standard dose of $2.5 \mathrm{~L} / \mathrm{ha}$ or a reduced dose of $2.0 \mathrm{~L} /$ ha for Foray ${ }^{\circledR} 76 \mathrm{~B}$ AVIO. This dose was also adequate for Rapax ${ }^{\circledR}$ AS AIR. The consistent employment of reduced doses is recommended in order to minimize the possible environmental impact and the costs related to product shipment and distribution [19]. 
In conclusion, our results confirmed the high efficiency of Btk applications to manage L. dispar infestations in the Mediterranean area, which represents an effective method to protect forests from defoliation. The two formulations containing different $B t k$ strains (i.e., ABTS-351, EG-2348) did not show significant differences in efficacy against gypsy moth larval population, providing a choice of alternative products to be considered in insect resistance management strategies. In addition, Foray ${ }^{\circledR} 76 \mathrm{~B}$ AVIO proved to be equally effective at a lower dose than that labeled, which allows treatment cost saving or the opportunity to use locally available budgets to increase the surfaces of the forest to be protected. On the other hand, the use of different doses might be calibrated according to the typical spatial heterogeneity of gypsy moth infestations, applying lower doses in less infested areas and standard doses in areas with higher population density.

Author Contributions: Conceptualization, A.L. and P.A.R.; methodology, A.L., L.R. and R.M.; formal analysis, R.M.; investigation, M.O. and R.M.; writing—original draft preparation, L.R., M.O. and R.M. All authors have read and agreed to the published version of the manuscript.

Funding: This research was partially funded by Fondo di Ateneo per la ricerca 2019 (Lentini and Ruiu L.) and by Regione Autonoma della Sardegna, Assessorato della Difesa dell'Ambiente through a scientific-technical collaboration agreement (Lentini and Ruiu P.A.).

Institutional Review Board Statement: Not applicable.

Informed Consent Statement: Not applicable.

Data Availability Statement: The data presented in this study are available on reasonable request from the corresponding author. The data are not publicly available due to private restrictions.

Conflicts of Interest: The authors declare no conflict of interest. The funders had no role in the design of the study; in the collection, analyses, or interpretation of data; in the writing of the manuscript, or in the decision to publish the results.

\section{References}

1. Aronson, J.; Pereira, J.S.; Pausas, J.G. Cork Oak Woodlands on the Edge: Ecology, Adaptative Management, and Restoration; Island Press: Washington, DC, USA, 2009.

2. Verdinelli, M.; Yakhlef, S.E.B.; Cossu, C.S.; Pilia, O.; Mannu, R. Variability of ant community composition in cork oak woodlands across the Mediterranean region: Implication for forest management. IForest 2017, 10, 707-714. [CrossRef]

3. Mannu, R.; Pilia, O.; Fadda, M.L.; Verdinelli, M. Variability of beetle assemblages in Mediterranean cork oak woodlands: Does the higher taxa approach reliably characterize a specific response to grazing? Biodivers. Conserv. 2018, 27, 3599-3619. [CrossRef]

4. Elkinton, J.S.; Liebhold, A.M. Population dynamics of gypsy moth in North America. Annu. Rev. Entomol. 1990, 35, 571-596. [CrossRef]

5. Luciano, P.; Prota, R. Insect pests in Sardinian cork-oak forests. IOBC/WPRS Bull 1995, 18, 1-7.

6. Davidson, C.B.; Gottschalk, K.W.; Johnson, J.E. Tree mortality following defoliation by the European gypsy moth (Lymantria dispar L.) in the United States: A review. For. Sci. 1999, 45, 74-84. [CrossRef]

7. Barbosa, P.; Martinat, P.; Waldvogel, M. Development, fecundity and survival of the herbivore Lymantria dispar and the number of plant species in its diet. Ecol. Entomol. 1986, 11, 1-6. [CrossRef]

8. Liebhold, A.M.; Gottschalk, K.W.; Muzika, R.M.; Montgomery, M.E.; Young, R.; O’Day, K.; Kelley, B. Suitability of North American Tree Species to the Gypsy Moth: A Summary of Field and Laboratory Tests; General Technical Report NE-211; USDA Forest Service: Radnor, PA, USA, 1995.

9. Floris, I.; Cocco, A.; Buffa, F.; Mannu, R.; Satta, A. Insect pests of Eucalyptus plantations in Sardinia (Italy). Redia 2018, 101, 61-71. [CrossRef]

10. Liebhold, A.M.; Gottschalk, K.W.; Mason, D.A.; Bush, R.R. Forest susceptibility to the gypsy moth. J. For. 1997, 95, 20-24.

11. Tiberi, R.; Branco, M.; Bracalini, M.; Croci, F.; Panzavolta, T. Cork oak pests: A review of insect damage and management. Ann. For. Sci. 2016, 73, 219-232. [CrossRef]

12. Cambini, A. Valutazione Dei Danni Causati Dagli Insetti Defogliatori Alla Quercia Da Sughero. In Proceedings of Atti del 1o Convegno Regionale del Sughero; Stazione Sperimentale del sughero: Tempio Pausania, Italy, 1971; pp. $327-339$.

13. Cambini, A. Effetti Delle Defogliazioni Singole e Duplici Sull'accrescimento Della Quercia da Sughero Quercus Suber L. Memoria 42; Stazione Sperimentale del Sughero: Tempio Pausania, Italy, 1975.

14. Smitley, D.R.; Davis, T.W. Aerial application of Bacillus thuringiensis for suppression of gypsy moth (Lepidoptera: Lymantriidae) in Populus-Quercus forests. J. Econ. Entomol 1993, 86, 1178-1184. [CrossRef] 
15. Webb, R.E.; Peiffer, R.; Fuester, R.W.; Thorpe, K.W.; Calabrese, L.; McLaughlin, J.M. An evaluation of the residual activity of traditional, safe, and biological insecticides against the gypsy moth. J. Arboric. 1998, 24, 286-293.

16. Luciano, P.; Lentini, A. Ten years of microbiological control program against lepidopterous defoliators in Sardinian cork oak forests. IOBC/WPRS Bull 2012, 76, 175-178.

17. Ruiu, L.; Mannu, R.; Falchi, G.; Braggio, A.; Luciano, P. Evaluation of different Bacillus thuringiensis sv kurstaki formulations against Lymantria dispar and Malacosoma neustria larvae infesting Quercus suber trees. Redia 2013, 96, 27-31.

18. Ruiu, L.; Mannu, R.; Olivieri, M.; Lentini, A. Gypsy Moth Management with LdMNPV Baculovirus in Cork Oak Forest. Forests 2021, 12, 495. [CrossRef]

19. Lentini, A.; Mannu, R.; Cocco, A.; Ruiu, P.A.; Cerboneschi, A.; Luciano, P. Long-term monitoring and microbiological control programs against lepidopteran defoliators in Sardinian cork oak forests (Italy). Ann. Silvic. Res. 2020, 45, 21-30. [CrossRef]

20. Mannu, R.; Cocco, A.; Luciano, P.; Lentini, A. Influence of Bacillus thuringiensis application timing on population dynamics of gypsy moth in Mediterranean cork oak forests. Pest. Manag. Sci. 2020, 76, 1103-1111. [CrossRef]

21. Reardon, R.C.; Podgwaite, J.D. Summary of efficacy evaluations using aerially applied Gypchek ${ }^{\circledR}$ against gypsy moth in the USA. J. Environ. Sci. Health 1994, 29, 739-756. [CrossRef]

22. Glare, T.R.; O'Callaghan, M. Bacillus thuringiensis. In Biology, Ecology and Safety; John Wiley \& Sons: New York, NY, USA, 2000.

23. Maczuga, S.A.; Mierzejewski, K.J. Droplet size and density effects of Bacillus thuringiensis kurstaki on gypsy moth (Lepidoptera: Lymantriidae) larvae. J. Econ. Entomol. 1995, 88, 1376-1379. [CrossRef]

24. Lentini, A.; Luciano, P. Bacillus thuringiensis in the management of gypsy moth (Lymantria dispar L.) in Sardinian cork-oak forests. IOBC/WPRS Bull 1995, 18, 104-109.

25. Lentini, A.; Cocco, A.; Luciano, P. Effects of Bacillus thuringiensis kurstaki treatments on gypsy moth population dynamics. IOBC/WPRS Bull 2012, 76, 171-174.

26. Ruiu, L.; Lentini, A.; Coinu, M.; Loi, A.; Serra, G.; Luciano, P. Comparative applications of Bacillus thuringiensis formulations against Lymantria dispar in Sardinian forests. IOBC/WPRS Bull 2012, 76, 185-190.

27. Boucias, D.G.; Pendland, J.C. Principles of Insect Pathology; Kluwer Academic Publisher: Boston, MA, USA, 1998.

28. Ellar, D.J.; Knowles, B.H.; Carroll, J.; Horsnell, J.; Haider, M.Z.; Ahmad, W.; Nicholls, C.N.; Armstrong, G.; Hodgman, T.C. Genetic and biochemical studies of the mechanism of action of Bacillus thuringiensis entomocidal-endotoxins. In Bacterial Toxins: Zentralblatt für Bakteriologie; International Medical Microbiology, Supplement 19; Rappuoli, R., Alouf, J., Freer, J., Fehrenbach, F., Wadstrom, T., Witholt, B., Eds.; Gustav Fischer: Stuttgart, Germany, 1990; pp. 409-506.

29. Crickmore, N. Beyond the spore-past and future developments of Bacillus thuringiensis as a biopesticide. J. Appl. Microbiol. 2006, 101, 616-619. [CrossRef]

30. Van Frankenhuyzen, K.; Fast, P.G. Susceptibility of Three Coniferophagous Choristoneura Species (Lepidoptera: Tortricidae) to Bacillus thuringiensis var. kurstaki. J. Econ. Entomol. 1989, 82, 193-196. [CrossRef]

31. Boulton, T.J.; Otvos, I.S.; Ring, R.A. Monitoring Nontarget Lepidoptera on Ribes cereum to Investigate Side Effects of an Operational Application of Bacillus thuringiensis subsp. kurstaki. Environ. Entomol. 2002, 31, 903-913. [CrossRef]

32. Pardo-López, L.; Soberón, M.; Bravo, A. Bacillus thuringiensis insecticidal three-domain Cry toxins: Mode of action, insect resistance and consequences for crop protection. FEMS Microbiol. Rev. 2013, 37, 3-22. [CrossRef]

33. Satinder, K.B.; Verma, M.; Tyagi, R.D.; Valéro, J.R. Recent advances in downstream processing and formulations of Bacillus thuringiensis based biopesticides. Process Biochem. 2006, 41, 323-342. [CrossRef]

34. Dubois, N.R. New laboratory and field developments in Bacillus thuringiensis and host susceptibility. In Proceedings of the U.S. Department of Agriculture Interagency Gypsy Moth Research Forum, Annapolis, MD, USA, 19-22 January 2003.

35. Cocco, A.; Cossu, A.Q.; Erre, P.; Nieddu, G.; Luciano, P. Spatial analysis of gypsy moth populations in Sardinia using geostatistical and climate models. Agr. For. Entomol. 2010, 12, 417-426. [CrossRef]

36. Mannu, R.; Gilioli, G.; Luciano, P. Occupancy of the territory by Lymantria dispar (L.) (Lepidoptera Erebidae) egg masses as a predictive index of damage. Redia 2017, 100, 157-165. [CrossRef]

37. R Development Core Team. R: A Language and Environment for Statistical Computing; R Foundation for Statistical Computing: Vienna, Austria, 2016.

38. Pünterner, W. Manual for field trials in plant protection. In Agricultural Division; Ciba-Geigy, Ltd.: Basle, Switzerland, 1981.

39. Therneau, T.M.; Grambsch, P.M. Modeling Survival Data: Extending the Cox Model; Springer: New York, NY, USA, 2000.

40. Therneau, T.M. Coxme: Mixed Effects Cox Models. R Package Version 2.2-5. Available online: https://CRAN.R-project.org/ package $=$ coxme (accessed on 24 April 2021).

41. Hothorn, T.; Bretz, F.; Westfall, P. Simultaneous inference in general parametric models. Biom. J. 2008, 50, 346-363. [CrossRef]

42. Alalouni, U.; Schädler, M.; Brandl, R. Natural enemies and environmental factors affecting the population dynamics of the gypsy moth. J. Appl. Entomol. 2013, 137, 721-738. [CrossRef]

43. Eichhorn, O. Experimental studies upon the parasitoid complex of the gypsy moth (Lymantria dispar L.) (Lep. Lymantriidae) in lower host populations in eastern Austria. J. Appl. Entomol. 1996, 120, 205-212. [CrossRef]

44. Hoch, G.; Zubrik, M.; Novotny, J.; Schopf, A. The natural enemy complex of the gypsy moth, Lymantria dispar (Lep. Lymantriidae) in different phases of its population dynamics in eastern Austria and Slovakia-A comparative study. J. Appl Entomol. 2001, 125, 217-227. [CrossRef] 
45. Contarini, M.; Luciano, P.; Pilarska, D.; Pilarski, P.; Solter, L.; Huang, W.F.; Georgiev, G. Survey of pathogens and parasitoids in late instar Lymantria dispar larval populations in Sardinia, Italy. Bull. Insectol. 2013, 66, 51-58.

46. Ladurner, E.; Benuzzi, M.; Franceschini, S. Bacillus thuringiensis sv kurstaki strain EG 2348: Effect of formulation on efficacy against tomato leaf miner (Tuta absoluta). IOBC/WPRS Bull 2011, 66, 39-42.

47. McGaughey, W.H.; Beeman, R.W. Resistance to Bacillus thuringiensis in Colonies of Indianmeal Moth and Almond Moth (Lepidoptera: Pyralidae). J. Econ. Entomol. 1988, 81, 28-33. [CrossRef]

48. Ferré, J.; Van Rie, J. Biochemistry and genetics of insect resistance to Bacillus thuringiensis. Annu. Rev. Entomol. 2002, 47, 501-533. [CrossRef]

49. Janmaat, A.F.; Myers, J. Rapid evolution and the cost of resistance to Bacillus thuringiensis in greenhouse populations of cabbage loopers Trichoplusia ni. Proc. Biol. Sci. 2003, 270, 2263-2270. [CrossRef]

50. Hemingway, J.; Ranson, H. Insecticide resistance in insect vectors of human disease. Ann. Rev. Entomol. 2000, 45, 371-391. [CrossRef] 